\title{
Monomorphous Plurihormonal Pituitary Gland Adenoma
}

National Cancer Institute

\section{Source}

National Cancer Institute. Monomorphous Plurihormonal Pituitary Gland Adenoma. NCI

Thesaurus. Code C154504.

A plurihormonal pituitary gland adenoma consisting of a single cell type producing two (or rarely more) hormones. (WHO 2017) 